\title{
HETEROGENEOUS ETHNIC DISTRIBUTION OF THE FACTOR V LEIDEN MUTATION
}

\author{
Rendrik F. Franco ${ }^{1}$, Jacques Elion ${ }^{2}$, Sidney E.B. Santos ${ }^{3}$, Amélia G. Araújol, \\ Marli H. Tavella ${ }^{l}$ and Marco A. Zago ${ }^{l}$
}

\begin{abstract}
Inherited resistance to activated protein $\mathrm{C}$ caused by the factor $\mathrm{V}$ Leiden (FVL) mutation is the most common genetic cause of venous thrombosis yet described, being found in $20-60 \%$ of patients with venous thrombophilia. A relationship between the FVL mutation and an increased predisposition to arterial thrombosis in young women was recently reported. We assessed the prevalence of the FVL mutation in 440 individuals ( 880 chromosomes) belonging to four different ethnic groups: Caucasians, African Blacks, Asians and Amerindians. PCR amplification followed by Mnll digestion was employed to define the genotype. The FVL mutation was found in a heterozygous state in four out of 152 Whites (2.6\%), one out of 151 Amerindians (0.6\%), and was absent among 97 African Blacks and 40 Asians. Our results confirm that FVL has a heterogeneous distribution in different human populations, a fact that may contribute to geographic and ethnic differences in the prevalence of thrombotic diseases. In addition, these data may be helpful in decisions regarding the usefulness of screening for the FVL mutation in subjects at risk for thrombosis.
\end{abstract}

\section{INTRODUCTION}

Venous thromboembolism is an important clinical condition currently understood as a multifactorial disease in which circumstantial acquired risk factors acting on genetically predisposed individuals lead to thrombosis (Seligsohn and Zivelin, 1997). The most important recognized genetic cause of venous thrombophilia is inherited resistance to activated protein C (APC) (Dählback et al., 1993). Inherited APC resistance is in most cases due to a single point mutation in the blood coagulation factor $\mathrm{V}$ gene: a $\mathrm{G} \rightarrow \mathrm{A}$ transition at nucleotide position 1691, which predicts the replacement of arginine (R) at amino acid position 506 by glutamine (Q) (Bertina et al., 1994). The mutant factor V is known as factor V R506Q or factor $\mathrm{V}$ Leiden (FVL). In addition to predisposing for venous thrombophilia, FVL has also been reported to be a genetic risk factor for premature cardiovascular disease (myocardial infarction) in women (Rosendaal et al., 1997).

The prevalence of FVL should be determined in different ethnic groups since this knowledge may influence decisions regarding the utility of mutation screening in individuals exposed to circumstantial risk factors for thrombosis. In addition, information concerning the heterogeneity of the prevalence of this important risk factor may help in understanding ethnic or geographical differences in the incidence of thrombotic diseases.

\footnotetext{
${ }^{1}$ Departamento de Clinica Médica, Faculdade de Medicina de Ribeirão Preto, Universidade de São Paulo, and Hemocentro Ribeirão Preto (FUNDHERP), 14049-900 Ribeirão Preto, SP, Brasil. Send correspondence to R.F.F. Fax: +55-16-633-4009. E-mail: rendri@hotmail.com

${ }^{2}$ Laboratoire de Biochimie Génétique, INSERM U458, Paris, France.

${ }^{3}$ Laboratório de Genética Médica e Humana, Universidade Federal do Pará, Belém, PA, Brasil.
}

In the present study, we investigated the prevalence of the FVL mutation in 440 individuals belonging to four different ethnic groups: Whites, African Blacks, Asians and Amerindians.

\section{SUBJECTS AND METHODS}

\section{Subjects}

FVL mutation analysis was performed in 440 individuals (880 chromosomes) belonging to four different ethnic groups: 152 Whites, 97 Blacks, 40 Asians and 151 Amerindians. The Whites were in most cases first or second generation descendants of Southern and Western European immigrants (mainly Portuguese, Spanish, Italian and German). The Black population sample included 97 African natives from Zaire and Cameroon, and the Asians were represented by 40 Japanese descendants. The 152 Amerindians came from seven tribes in the Brazilian Amazon region (20 Arara, 20 Kayapo, 20 Wayampi, 21 Wayana-Apalai, 21 Yanomami, 23 Awa-Guaja and 26 Poturujara). All individuals investigated were unrelated, apparently healthy, and denied any racial admixture for at least three generations. The subjects participated in the study as volunteers.

\section{Methods}

Genomic DNA was obtained from peripheral blood leucocytes by standard methods (Sambrook et al., 1989). Exon 10 of the factor V gene was amplified by PCR, and the amplified products were digested with the restriction enzyme $M n l I$ to define the genotypes. The primers and PCR conditions employed have been reported elsewhere (Bertina et al., 1994). A test for the homogeneity of proportions was used to evaluate differences in allele frequencies between populations. 


\section{RESULTS AND DISCUSSION}

A heterogeneous distribution was observed for the prevalence of the FVL mutation in individuals with different ethnic backgrounds. The FVL mutation was detected in heterozygous state in 4 out of 152 Whites $(2.6 \%)$ and in 1 out of 151 Amerindians $(0.6 \%)$ but was absent among 97 African Blacks and 40 Asians. No homozygote for the FVL mutation was observed.

The prevalence of the FVL mutation in Whites confirmed that this mutation is relatively common among Brazilian Caucasians, in agreement with a previous study performed in the Brazilian population (Arruda et al., 1995). In contrast, FVL was not found among the Asians and African Blacks studied. These findings agree with the suggestion that the mutation occurred 21,000-34,000 years ago, after the divergence of non-Africans from Africans and after the divergence of Caucasians and Mongolians (Zivelin et al., 1997). The finding of the FVL mutation in one Amerindian was unexpected, since the mutation was probably absent in the original populations of America (Zivelin et al., 1997). Even though the admixture with Blacks and Caucasians was evaluated at less than $2 \%$ for these Amerindian populations on the basis of classic protein markers (Salzano and Callegari-Jacques, 1988), we have observed the presence of alleles of Black origin among Amerindians (Zago et al., 1995), and the finding of one heterozygote may be the result of some admixture with Whites.

The absence of the FVL mutation in African Blacks was particularly interesting. Since virtually no racial admixture was expected to exist in this sample, it may be considered highly representative of a native Black population. Hence, our data provide further evidence that the FVL mutation is absent among Blacks, and suggest that the finding of this mutation among Afro-Americans in previous studies (Arruda et al., 1996; Gregg et al., 1997) might well be the result of miscegenation with Whites. The prevalence of venous thromboembolism was claimed to be lower among native Africans compared to other human populations (Thomas et al., 1960; Gore et al., 1964; WHO, 19931994). Our data agree with these observations since this lower incidence may partly reflect the absence of the most important known cause of venous thrombophilia (the FVL mutation) in this ethnic group. The possibility that FVL might be a genetic risk factor for arterial thrombotic disease has been investigated in several studies, but with conflicting results (Prohaska et al., 1995; Kontula et al., 1995; van der Bom et al., 1996; Foley et al., 1997). However, a recent study demonstrated a clear relationship between the presence of FVL and increased predisposition for myocardial infarction in young women (Rosendaal et al., 1997). In particular, the absence of FVL among African Blacks may contribute to the low incidence of cardiovascular disease observed among African natives (Hames and Greenlund, 1996). These studies indicate that the hetero- geneous ethnic distribution of the FVL mutation may contribute to our understanding of differences in the prevalence of thrombotic vascular disease in different human populations.

The identification of the FVL mutation may affect the adoption of prophylactic and therapeutic regimens for venous thrombosis (Dählback, 1997). For this reason, determining the prevalence of the FVL mutation in different populations has become an important means of taking decisions about which subjects at risk for thrombosis should be stratified for the FVL mutation. The data of this study should be helpful in formulating decisions about screening for FVL in patients of different populations, including the Brazilian population, since the results strengthen the observation that FVL is not prevalent among non-Caucasians (Rees et al., 1995; Arruda et al., 1996; Dählback, 1997; Pepe et al., 1997).

\section{ACKNOWLEDGMENTS}

We are grateful to all individuals who participated in this study. Research supported by FAPESP, FINEP, CNPq and Grant TS3*-CT93-0244 from the European Union. Publication supported by FAPESP.

\section{RESUMO}

Resistência à proteína $\mathrm{C}$ ativada associada à mutação do fator V Leiden (FVL) é a mais prevalente causa genética de trombose venosa conhecida, sendo encontrada em 20 a $60 \%$ dos pacientes com trombofilia. Adicionalmente, uma associação entre a mutação do FVL e predisposição aumentada para doença cardiovascular prematura em mulheres foi recentemente descrita. No presente estudo nós determinamos a prevalência da mutação do FVL em 440 indivíduos (880 cromossomos) de 4 grupos étnicos diferentes: caucasóides, negros africanos, asiáticos e ameríndios. Amplificação por PCR seguida de digestão com a enzima de restrição $M n l$ I foi utilizada para definição do genótipo. A mutação do FVL foi encontrada em heterozigose em 4 de 152 caucasóides (2,6\%), 1 de 151 ameríndios $(0,6 \%)$ e esteve ausente em 97 negros africanos e 40 asiáticos. Nossos resultados confirmam que o FVL apresenta distribuição heterogênea em diferentes populações humanas, fato que pode contribuir para diferenças étnicas e geográficas na prevalência de doenças trombóticas. Adicionalmente, estes dados podem ser úteis para a definição de estratégias de rastreamento desta mutação em indivíduos sob risco para desenvolvimento de trombose, na população brasileira.

\section{REFERENCES}

Arruda, V.R., Annichino-Bizzacchi, J.M., Costa, F.F. and Reitsma, P.H. (1995). Factor V Leiden (FVQ506) is common in the Brazilian population. Am. J. Hematol. 39: 242-243.

Arruda, V.R., von Zuben, P.M., Soares, M.C.P., Menezes, R., AnnichinoBizzacchi, J.M. and Costa, F.F. (1996). Very low incidence of Arg506 $\rightarrow$ Gln mutation in the factor V gene among the Amazonian Indians and the Brazilian Black population. Thromb. Haemostasis 75: $859-863$

Bertina, R.M., Koeleman, B.P.C., Koster, T., Rosendaal, F.R., Driven, 
R.J., de Ronde, H., van der Velden, P.A. and Reitsma, P.H. (1994). Mutation in blood coagulation factor $\mathrm{V}$ associated with resistance to activated protein C. Nature 369: 64-67.

Dählback, B. (1997). Resistance to activated protein C as a risk factor for thrombosis: molecular mechanisms, laboratory investigation, and clinical management. Semin. Hematol. 34: 217-234.

Dählback, B., Carlsson, M. and Svensson, P.J. (1993). Familial thrombophilia due to a previously unrecognized mechanism characterized by poor anticoagulant response to activated protein C: prediction of a cofactor to activated protein C. Proc. Natl. Acad. Sci. USA 90: 10041008.

Foley, P.W.X., Irvine, C.D., Standen, G.R., Morse, C., Smith, F.T., McGrath, C., Baird, R.N. and Lamont, P.M. (1997). Activated protein $\mathrm{C}$ resistance, factor $\mathrm{V}$ Leiden and peripheral vascular disease. Cardiovasc. Surg. 5: 157-160.

Gore, I., Hirst, A.E. and Tanaka, K. (1964). Myocardial infarction and thromboembolism. Arch. Intern. Med. 113: 323-330.

Gregg, J.P., Yamane, A.J. and Grody, W.W. (1997). Prevalence of factor $\mathrm{V}$ Leiden mutation in four distinct American ethnic populations. Am. J. Hum. Genet. 73: 334-336.

Hames, C.G. and Greenlund, K.J. (1996). Ethnicity and cardiovascular disease: the Evans County heart study. Am. J. Med. Sci. 311: 130-134.

Kontula, K., Ylikorkala, A., Miettinen, H., Vuorio, A., KauppinenMäkelin, L., Hämäläinen, L., Palomäki, H. and Kaste, M. (1995). Arg506Gln factor V mutation (factor V Leiden mutation) in patients with ischaemic cerebrovascular disease and survivors of myocardial infarction. Thromb. Haemostasis 73: 558-560.

Pepe, G., Rickards, O., Vanegas, O.C., Brunelli, T., Gori, A.M., Giusti, B., Attanasio, M., Prisco, D., Gensini, G.F. and Abbate, R. (1997). Prevalence of factor V Leiden mutation in non-European populations. Thromb. Haemostasis 77: 329-331.

Prohaska, W., Mannebach, H., Schmidt, M., Gleichmann, U. and Kleesiek, K. (1995). Evidence against heterozygous coagulation factor V $1691 \mathrm{G} \rightarrow$ A mutation with resistance to activated protein C being a risk factor for coronary artery disease and myocardial infarction. J. Mol. Med. 73: 521-524.

Rees, D.C., Cos, M. and Clegg, J.B. (1995). World distribution of factor V Leiden. Lancet 346: 1133-1134.

Rosendaal, F.R., Siscovick, D.S., Schwartz, S.M., Beverly, R.K., Psaty, B.M., Longstreth, W.T., Ragunathan, T.E., Koepsell, T.D. and Reitsma, P.H. (1997). Factor V Leiden (resistance to activated protein $\mathrm{C}$ ) increases the risk of myocardial infarction in young women. Blood 89: 2817-2821.

Salzano, F.M. and Callegari-Jacques, S.M. (1988). South American Indians. A Case Study in Evolution. Clarendon Press, Oxford

Sambrook, J., Fritsch, E.F. and Maniatis, T. (1989). Molecular Cloning. A Laboratory Manual. 2nd edn. Cold Spring Harbor Laboratory Press, Cold Spring Harbor.

Seligsohn, U. and Zivelin, A. (1997). Thrombophilia as a multigenic disorder. Thromb. Haemostasis 78: 297-301.

Thomas, W.A., Davies, J.N.P., O'Neal, R.M. and Dimakulangan, A.A. (1960). Incidence of myocardial infarction correlated with venous and pulmonary thrombosis and embolism. Am. J. Cardiol. 1: 41-47.

van der Bom, J.G., Bots, M.L., Haverkate, F., Slagboom, P.E., Meijer, P., de Jong, P.T., Hofman, A., Grobbee, D.E. and Kluft, C. (1996). Reduced response to activated protein $\mathrm{C}$ is associated with increased risk for cerebrovascular disease. Ann. Intern. Med. 125: 265-269.

World Health Organization (1993/1994). World Health Statistical Annual. Who Publications, Geneva.

Zago, M.A., Santos, E.J.M., Clegg, J.B., Guerreiro, J.F., Martinson, J.J., Norwich, J. and Figueiredo, M.S. (1995). $\alpha$-Globin gene haplotypes in South American Indians. Hum. Biol. 67: 535-546.

Zivelin, A., Griffin, J.H., Xu, X., Pabinger, I., Samama, M., Conard, J., Brenner, B., Eldor, A. and Seligsohn, U. (1997). A single genetic origin for a common Caucasian risk factor for venous thrombosis. Blood 89: 397-402.

(Received August 13, 1998) 
